\title{
On Teaching Reform of the Accounting Major in Colleges and Universities in China
}

\author{
Xiling Dai \\ School of Business Administration, Shenyang University \\ Shenyang 110044, Liaoning, China \\ E-mail: sydxdxl@163.com
}

Received: January 20, $2011 \quad$ Accepted: January 28, $2011 \quad$ doi:10.5539/ass.v7n5p132

\begin{abstract}
This paper discussed the teaching reform direction in the accounting major in colleges and universities in four aspects. Firstly, the author discussed the cultivation goal and suggested re-positioning the cultivation goal. Secondly, the author discussed the reform direction of classroom teaching from the three perspectives of teaching content, teaching method and teaching means. Then, the author analyzed issues existing in practical teaching and put forward some reform countermeasures. Finally, the author pointed out the reform direction for teachership construction by analyzing existing issues in teaching staff at present.
\end{abstract}

Keywords: Colleges and universities, Accounting major, Teaching reform

With continuous development of the market economy, the economic business of enterprises becomes more and more complicated, which poses higher and higher demands on theory and practice in accounting. Thus, we are in an urgent need of a bass of high quality and compound talents in accounting with sustainable innovative capacity and rational knowledge structure who are well trained. University students majoring in accounting in colleges and universities at present will necessarily turn to be the main force within the field of accounting and their moral, cultural, business and technical quality will exert significant influences upon reform and development of accounting in China. Thus, teaching of accounting in colleges and universities has to keep up with the development pace of the social economy, come to understand demands of the accounting profession on university students and put forth efforts to cultivate more talents in accounting who can adapt to social demands. Nevertheless, considering the employment situation of graduates majoring in accounting in recent years, the effect of teaching in accounting in colleges and universities is not as ideal as has been imagined. Quite a lot of employing units react that the newly recruited graduating students are incapable of connecting theory with practice, which is not favorable for benign development of education in colleges and universities. Therefore, teaching reform in the major of accounting in colleges and universities in required by the circumstance. The author of this article expressed some humble opinions as for teaching reform in the major of accounting in colleges and universities from the four aspects of the cultivation goal, classroom teaching, practice teaching and construction of the teachership.

\section{Cultivation goal}

For the time being, quite a large number of graduates are unable to seek for appropriate jobs. Some students believe they have learnt nothing in the school even if they have found a job or think what they have learnt is useless. The reason for this phenomenon is that some universities are unlikely to correctly position the cultivation goal for the major of accounting, which causes undergraduates who major in accounting to fail to achieve the demand of the society on the talents it requires in terms of knowledge structure and capacity structure. Thus, reform in teaching of accounting major in colleges and universities has to begin with accurate positioning of the cultivation goal. That is to say, they have to keep a foothold in reality of China by taking into consideration the characteristics of the times and confirm an appropriate cultivation goal.

Considering the reality at present, the author believes that the cultivation goal of the major of accounting in colleges and universities in China should be based on cultivation of compound talents in accounting with a combination of morality, knowledge and capacity and with high quality. Its connotation includes the following several aspects. Firstly, colleges and universities should pay attention to cultivating the quality of students and enable them to become professional personnel in the future with stable professional ideas and lofty professional 
ethics. Secondly, colleges and universities ought to make an attempt to cultivate talents in accounting with comprehensive knowledge so as to adapt to more and more complicated demands required by accounting in the future. Finally, colleges and universities have to concentrate on cultivating the capacity of students.

In order to guarantee implementation of this cultivation goal, the accounting major in colleges and universities has to conduct corresponding supporting reform. The author explained in details plans of reform from the three aspects of classroom teaching, practice teaching and construction of teachership.

\section{Classroom teaching}

Most students receive higher education in classrooms. Thus, classroom teaching is an important aspect for teaching reform in colleges and universities. In this article, the author made a discussion from the three aspects of teaching content, teaching method and teaching means.

\subsection{Teaching content}

Content of teaching is mainly reflected in teaching materials, since quality of teaching materials is directly connected with quality of teaching and also directly reflects the developmental level of higher education and scientific research. Hence, construction and development of teaching materials is of crucial importance to success or failure of teaching reform.

For the time being, there are lots of versions of accounting teaching materials in the market, but their quality is far from satisfying. Considering the current accounting teaching materials, there are mainly the following two problems. On one hand, the content of teaching materials is laggard. Content of some teaching materials are not updated in time according to new accounting standard. Content of some other teaching materials is weak in terms of practical application, and is disconnected with the demands of the market. On the other hand, content of teaching materials lays particular emphasis on domestic accounting standard. Integration of contemporary economy is developed rapidly, and the international economic exchange becomes more and more frequent. Thus, demands of enterprises on the knowledge structure of accountants have also been greatly changed. That is, enterprises ask them to simultaneously master both domestic accounting standard and international accounting standard. Thus, it can be seen, the setting system of the current accounting teaching materials in which domestic accounting standard is regarded as the center can no longer adapt to demand of the social and economic development.

In order to alter this status quo, accounting major in colleges and universities have to be encouraged to innovate and formulate a series of supporting material system with Chinese characteristics according to new demand of the Twenty-first Century on accounting talents.

Reform of teaching content has to be based on quality-oriented education, with the emphasis of cultivating students' innovative capacity and the fundamental target of creating compound accounting talents with high quality. It is suggested that direction of reform in teaching materials in the future should start from the following several aspects. Firstly, the epochal character of teaching material content should be strengthened. Colleges and universities ought to make adjustment on teaching content according to the latest achievements in construction and development of domestic disciplines and accelerate updating of teaching materials. Secondly, the practicality of teaching content should be intensified. For the time being, exams closely related with accountants include Accounting Qualification Certificate, Accounting Professional Technician Qualification Examination and Certificate Public Accountant Examination (CPA), etc. when compiling teaching materials, university teachers should make an overall plan and take all factors into consideration in terms of the knowledge scope of these exams and attempt to help students pass these exams successfully and seek for an ideal job after graduation. Thirdly, the internationalization of content of teaching materials should be reinforced. When compiling teaching materials, university teachers should take an initiative to draw close to international accounting standard and part of courses can select directly the original English version of the teaching materials. This practice can help students improve their English level and their international competitive force.

\subsection{Teaching method}

At present, most colleges and universities hold teaching activities by regarding teachers as the subject. That is to say, teachers offer one-way cramming knowledge instilment, while students assimilate knowledge mechanically and passively. This concept of talent cultivation in which imparting text knowledge is the center has no way to cultivate compound accounting talents with high quality required by the society. In the past several years, colleges and universities have been aware of the seriousness of the above problem and their emphasis on reform of teaching method is strengthened day by day. Even some colleges and universities have already achieved definite achievements in their activities of teaching reform. 
Given experiences and lessons in former teaching reform in colleges and universities, the author believed that, reform of teaching method should begin with cultivation goal, combine characteristics of the course, take an initiative in innovation on the basis of inheriting merits of traditional teaching methods, and set up the heuristic bidirectional imparting teaching method system in which "students are the subject and teachers are the director".

Under this new type of teaching method system with "coexistence of succession and innovation", there are quite a lot of colorful and various teaching methods to be selected, such as, heuristic questioning method, discussion teaching method, guided learning method with combination of systematic teaching and self-learning of students and case method of instruction, etc.

The key to carry out this new type of teaching method system lies in delimiting the scope of courses centered with traditional teaching methods. According to the author of this article, for fundamental courses, the traditional teaching method should be the major teaching method, supplemented by teaching methods in the new type of teaching method system, while for other courses, we should positively employ one sort or multiple sorts of teaching methods in the new type of teaching method system, with the goal to attain the best teaching quality and teaching effect. For example, the course of "Introduction to Accounting" is the basic course, and a threshold course to help students to learn accounting. Thus, a systematic theoretical learning and teaching of accounting is indispensable. With the traditional teaching method, usually teaching impart their knowledge and experiences to students that they have learnt and accumulated for many years in a clear way. This strong coherence is helpful for systematic learning of students. Thus, this kind of teaching method means a lot to teaching of a basic course. At the same time, if we adopt heuristic questioning method in the process of basic course teaching, namely, asking several "why" questions in the process of teaching, to encourage students to reflect and question boldly, then it will be of great help to improve students' capacity. When students have mastered some definite basic knowledge, we should teach them with a new type of teaching method system. For instance, the course of "accounting code and professional ethics" includes several theoretical points. Hence, if we adopt the traditional teaching method to teach them, students will, without doubt, feel tedious and the teaching effect will not be as good as imagined. Nevertheless, if we adopt the discussion teaching method, that is, to find some theoretical problems with realistic significance and let students look for relevant document and materials after the class and put forward their own viewpoints, or exchange views and discuss in the classroom with a small group as the unit, while teachers offer appropriate implication, guidance and summary, they it is likely to cultivate students' analytical ability, expressive ability and innovative ability, which corresponds with the cultivation goal.

\subsection{Teaching means}

Reform of teaching means refers to alteration of teaching means from the traditional technique to the modern technique, that is, switch from the laggard "blackboard chalk" teaching means to such modern teaching means of multi-media and web-based instruction, etc. For the time being, most colleges and universities in China have already been aware of the importance of modern teaching means and quite a large number of colleges and universities have set up a certain amount of various modernized education facilities, such as, language labs, multimedia classrooms and computer labs. However, these education facilities are far from satisfying the need of all, so the effect of teaching is not as good as imagined. In addition, the quality of multimedia teaching is not that good, and the phenomenon of merely moving a house for blackboard-writing still exists. Thus, colleges and universities ought to take into consideration the actual situation, go deep into reform, vigorously develop modern teaching means and improve teaching quality so as to realize the established cultivation goal.

With regard to experiences and lessons in former teaching reform in colleges and universities, the author of this article put forward the following several suggestions for reform of teaching means. Firstly, construction of modernized education facilities should be strengthened. Only if the problem of insufficiency in teaching resources is resolved, can colleges and universities have the condition to encourage teachers to employ modern teaching means. Secondly, at the time when further promoting multimedia teaching means, teachers should improve the quality of courseware. Manufacturing of courseware has to be vivid and combine characters, pictures, sound and autokinetic effect in an organic way. In the mean while, we should combine the new type of teaching method system with modern teaching means, pay attention to the bidirectional communication between teachers and students, enlighten students to ponder over problems and focus on cultivation of students' capacity and improvement of their quality. Thirdly, we should try to develop web-based instruction. There are a variety forms of web-based instruction, such as, setting of internet course, network FAQ, network test and network practice, etc. With this kind of modern teaching means, students have the freedom to arrange their time to learn online, download the teaching plan of their teaching anywhere and ask question online at any time and get timely reply. Teachers are able not to be restrained by the time and place of a class, and their job is to carefully and timely upload their teaching plan, publicize a course bulletin and answer questions of students. The colleges and universities can also avoid some trivial affairs, such as arranging the classroom, so as to diminish unnecessary 
wastes in man power, financial power and material power, and economize expenses. Thus, it can be seen that, compared with the traditional teaching means, web-based teaching has lots of advantages. Thus, it is a developmental trend in modernized education to apply network technique to conduct web-based instruction.

\section{Practical teaching}

Reform of classroom teaching may improve the quality of theoretical teaching and enable students to possess deep theoretical foundation. However, as for university graduates, in addition to solid theory, they have to have strong capacity to complete practical work. In such way, they are able to adapt to a working position as soon as possible in the future. Thus, colleges and universities ought to lay emphasis on practical teaching and cultivate students' innovative spirit and practical ability through practical teaching so as to satisfy demands of employing units.

At present, there are the following several problems that generally exist in the practical teaching in colleges and universities. Firstly, under the influence of the traditional concept, some colleges and universities mistakenly believe that experimental classes only matter to students majoring in science and engineering, so they show preference for the talent cultivation mode which lays emphasis on theory but ignores practice, which causes experimental teaching in accounting to be unable to be conducted in time. Secondly, teaching materials employed in practical teaching usually tend to merely involve the economic business of one manufacturing enterprise in a certain month, and their requirement for students is nothing more than learning to keep accounts and submit an expense account. This tedious and obsolete content and low teaching level requirement are unfavorable for cultivation of compound talents with high quality. Finally, as a result of limited funds, it is quite difficult for colleges and universities to find internship units for their students. Some colleges and universities intend students to get in touch with internship units by themselves. Nevertheless, actually quite a lot of students only have their names in a unit, but they haven't really finished the task of internship. Therefore, campus internship in a large number of universities exists in name only, unable to help students realize organic combination of theory and practice, and is, thus, unfavorable for the ultimate fulfillment of the cultivation goal.

In order to resolve the above issues in practical teaching, the author believes that colleges and universities can make efforts from the following several aspects. Firstly, they ought to change the idea of "emphasis on theory and ignorance of practice" and take an initiative to explore a talent cultivation mode with cooperation among industries, universities and research institutions so as to enhance the teaching effect and quality of talent cultivation. Secondly, colleges and universities ought to strengthen construction of the teaching materials. Content of the teaching materials should be concerned with business operation of all industries. Then, students are able to get all-round training and adapt to requirements of the job as soon as they can after graduation. In addition, what a modern enterprise calls for are advanced talents in accounting who are able to take part in prediction and decision making and make the financial analysis. Therefore, content of the teaching materials should not be confined to cultivation of the ability of financial accounting, but should develop towards the diversified direction. Thirdly, colleges and universities should reinforce investment in campus internship expenditure, and, at the same time, recommend competent education departments of the nation to allocate funds for them. With enough funds, colleges and universities are able to establish long term stable cooperative relationship with employing units and offer internship bases for university students to link up with employment in the future. As for those excellent graduates, employing units can consider continuing to employ them, in which way they can stimulate students' enthusiasm and iniative.

\section{Construction of teachership}

College and universities teachers burden the sacred duty to impart knowledge and educate students, so their comprehensive quality and professional skill are directly connected with the quality of teaching and effects of talent cultivation. However, for the time being, the level of teachership in colleges and universities in China is not quite ideal, with major problems reflected in the two aspects of low theoretical level and insufficient practical experiences. Since a large majority of accounting teachers enter the campus after their graduation from the campus, so they are lacking in experiences in working in enterprises, and tend to bite off more than they can chew in guiding the practical teaching of students. In addition, since the upgrading speed of knowledge is quite fast and some teachers are not "charged" in time, their theoretical level is not high and they have no means to satisfy requirements of students in their class. With regard to the above problem, the author put forward the following two countermeasures. On one hand, teachers ought to pay close attention to the latest trend of development of the major of accounting, master the latest academic research achievements in time and gradually improve their own theoretical level, so as to impart the latest knowledge to their students. On the other hand, colleges and universities should keep regular contact with the occupational field of accounting and have regular communication. Under the condition not affecting teaching, they should positively encourage accounting teachers to go out of the campus and go deep to enterprises and accounting firms to undertake part-time jobs. In 
this way, they have the opportunities to come to contact and understand the accounting practice, accumulate social practical experiences and improve the ability of teachers to realize, analyze and resolve the actual problems and lay solid foundation for enhancing the quality of practical teaching.

\section{References}

Liu, Qiuyue \& Shi, Hongmei. (2001). On Reform of Accounting Teaching in the Twenty-first Century. Journal of Henan Vocation-Technical Teachers College (Vocational Education Edition), 4.

Liu, Yan. (2005). Reform of Accounting Teaching in Colleges and Universities. Journal of Zhuzhou Institute of Technology, 3.

Yang, Xiaoyu. (2004). The Employment of College Students and the Reform of College Accounting Teaching. Journal of Daqing College, 4.

Zhang, Mingyu, Zhang, Huide, Jin, Jinghong \& Huang, Haiying. (2005). Reform and innovation of experimental teaching system for accountant discipline. Journal of Technology College Education, 12.

Zou, Min. (2004). A Talk on Carrying Out Higher Learning Institution's Accounting Teaching Activities Effectively. Journal of Hunan Industry Polytechnic, 6. 